\title{
The Commerce Clause From Expansion To Extortion
}

Patrick J. Reville, B.B.A., J.D., Iona College, USA

William A. Bottiglieri, M.B.A., C.P.A., J.D., Iona College, USA

\begin{abstract}
The Commerce Clause of the United States Constitution gave the federal government power over foreign trade, trade with the Indian tribes and trade "among several states." By lack of further enumeration and the passage of the Tenth Amendment to the Constitution, it would be reasonable to conclude that commerce that is truly intrastate would, therefore, be within the regulatory province of the states. In fact, that was the interpretation initially reached and subsequently followed by the United States Supreme Court. But in 1942, that changed and, over the course of the following 60+ years, to date the Court has concluded, by an expansive interpretation of that federal power granted, that Congress and the federal government have virtually unbridled power to regulate not only those areas that would traditionally be considered "commerce" or "interstate commerce", but, moreover, in areas that seemingly have nothing to do with commerce, interstate, or otherwise. This paper will trace the journey that the justices have taken down this judicial interstate highway and the methods that the federal government has employed to achieve its objectives. Hence, the subtitle of this paper: From Expansion to Extortion.
\end{abstract}

Key Terms: Interstate Commerce, Federal Power, Constitutional Expansion.

\section{THE HISTORY}

\section{A. The Commerce Clause}

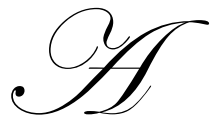

rticle I, Section 8 of the United States Constitution states that Congress and, therefore, the federal government, has the power "to regulate commerce with foreign nations, among several states, and with the Indian Tribes."(1) Shortly after ratification, the first ten amendments were attached to the Constitution and commonly became known as the Bill Of Rights. The Tenth of said Amendments reads: The powers not delegated to the United States by the Constitution, nor prohibited by it to the states, are reserved to the states respectively, or to the people. (2) Reading these two provisions in context, the reasonable conclusion reached is that the federal government has the power over interstate commerce ("among several states"), but that commerce wholly within a state (intrastate commerce) would be the province of the states to regulate.

\section{B. The Early Years}

In Gibbons v. Ogden (3), the power of the federal government over interstate commerce was confirmed. A New York State law prohibiting vessels that had federal authority to navigate U.S. waters was held unconstitutional. Yet, it was therein also acknowledged that commerce, in effect, did not cross state borders, and that remained between individuals within a state, would not be within the province of the federal government under the commerce clause.(4) Such was the approach taken by Congress for over a century to follow.

\section{The New Deal}

The stock market crash of 1929 is the focal point of events that brought on The Great Depression, at least as it affected life in the United States. Congress had decided some ten years earlier to pass a Constitutional Amendment (5) basically outlawing alcoholic beverages in the U.S. The Eighteenth Amendment, and its roughly 
thirteen year lifespan commonly known as "Prohibition", although later characterized as a "noble experiment" was totally unsuccessful in stopping people from drinking. The mood of the populace in the U.S., particularly after the crash, was depressed, to say the least. Enter Franklin D. Roosevelt and the New Deal.

On December 5, 1933, the Twenty-First Amendment (6) of the U.S. Constitution was ratified, expressly repealing the Eighteenth Amendment. One theory states, that if the people are going to be miserable with their economic situation, they might as well have some beer to legally cry in. And some say the federal government might as well generate some revenue by taxing the production, transportation, sale and consumption of alcohol, such activities that had become a huge income source to-if not having played a major role in-the conception of modern day organized crime.

President Roosevelt's effort to "get the country going again" resulted in Congress enacting various pieces of legislation, a number of which were struck down by the Supreme Court as an overreaching of the federal power contained in the Commerce Clause. The Railroad Retirement Act of 1934 was nullified in 1935 because its attempt to mandate retirement plans for railroad workers was interpreted as an attempt to legislate a perceived social good (pensions for retirees), but the same was not a rule or regulation of commerce and transportation between the states. (7)

In the Schechter Poultry Corp. case (8), it was unanimously held that the poultry slaughterhouse workers in Brooklyn, N.Y., could not legitimately have their wages and hours dictated by federal law, because the Commerce Clause did not give Congress power over them, in that the slaughtering and sales of the poultry were local in nature and fact, and not transactions in interstate commerce.

Relieving the plight of the coal miners across the nation was part of the New Deal legislation known as the Bituminous Coal Conservation Act of 1935. It also was struck down as unconstitutional in the Carter Coal Company case.(9) It was argued that interstate commerce was greatly affected by the relationship between employer and employee and the working conditions and collective bargaining activities of the miners. This argument was rejected by the Court, stating that "the evils are all local evils over which the federal government has no legislative control."(10)

Understandably, President Roosevelt could not have been pleased, to say the least, with the string of decisions coming from the Court, crimping, from his perspective, his attempts to raise the country from its economic plight. His response was to threaten to stack another five justices onto the Court by appointment, and thereby solve his problem. Admittedly, this was a novel interpretation of the concept of checks and balances.

\section{A Crack in the Door}

Just as in the book and movie The Godfather, when the mogul movie producer woke up with the head of his prize race horse in bed with him, the message got through. In 1937, the Supreme Court ruled that seemingly intrastate activities might have such a closeness and substantial relation to interstate commerce that control (by the federal government) would not only be appropriate, but essential to protect commerce from obstructions and burdens.(11) Here was the crack in the door, a break in the traffic that could and would put Congress on the onramp to the mother of all superhighways of regulation.

\section{E. The Door is Opened}

In 1942, the Court took advantage of the crack in the door created by N.L.R.B v. Jones (12) and decided that a local dairy farmer in Ohio, growing wheat that was used partially for local re-sale, partially to feed his stock, partially for seed, and partially for making flour for the use by his own family, was held to be so involved in and/or affecting interstate commerce that a fine imposed upon him under federal law quota system would stand. The Court upheld the imposition of a $\$ 117.11$ penalty for violation of the federal Agricultural Adjustment Act of 1938.(13) It is somewhat astounding that a case involving a $\$ 117$ fine would even find its way to the United States Supreme Court, much less become the vehicle that the federal government would use to steamroll its way for decades into areas that had heretofore been under state and local regulation and control. 


\section{THE EXPANSION \& EXTENSION}

\section{A. The Civil Rights Act and Loan Sharking}

In the turbulent 1960's, the reach of the Commerce Clause was stretched into the area of Civil Rights. It was held that whether a person could sit at a local lunch counter, in an admittedly obscure local restaurant, so substantially affected interstate commerce that federal law mandated that discrimination and refusal to serve based on race made such conduct a federal matter, and therefore, illegal.(14) While discrimination, based on race, or otherwise, can be viewed as an evil that should be eradicated. The issue raised is: "Is this a federal interstate commerce matter?"

In 1971, the Supreme Court decided that the practice of lending money at exorbitant interest rates so affected interstate commerce, that federal law criminalizing and punishing same was constitutional, despite the fact that the lending and collecting was strictly local in nature.(15) Ironic, it will turn out, that the practice of extortion in collecting purely local loans was ruled as interstate commerce, when it will be posed as to whether or not the federal government's use of the Commerce Clause itself has been characterized as a form of extortion.

\section{B. Hit The Road, Jack}

Congress, thereafter, literally took its Commerce Clause show on the road. In 1981, The Supreme Court found that the prohibition by the state of Ohio of tandem trailers on interstate highways within its borders was in violation of the Commerce Clause of the Constitution.(16) Similarly, when Governor William O'Neil tried to stand at the border of the state of Connecticut, in the person of Connecticut state troopers, in full battle gear, to force drivers pulling tandem trailers to exit I-95 without entry into Connecticut, forcing them to jam the streets and get stuck under the low bridges of downtown Port Chester, N. Y., the federal government moved instantly and succeeded quite quickly in obtaining an injunction precluding Connecticut from the tandem trailer ban.(17)

\section{THE EXTORTION}

\section{A. One For The Road}

When the Twenty-First Amendment repealed the Nineteenth Amendment, and the federal government, at least on the face of the matter, got out of the alcohol prohibition and regulation business, the states, it would be reasonably argued, buy virtue of the Tenth Amendment (as cited above) and other principles of law, were back in business. The states across the country were free to, and did, set the minimum age for purchasing and/or consuming alcoholic beverages. In those turbulent 1960s mentioned above, a substantial part of the anti-Viet Nam War rhetoric evolved around the mandatory draft that was in place, requiring military service of young men. "Hell No, We Won't Go" was shouted in the streets. In addition, a continuous argument was made that since some states did not allow a person to vote until age 21, but you could be drafted and sent to fight in Viet Nam at age 18, this was unfair if not illegal. A similar cry was made that how could a young man be called to defend his country at age 18 when he couldn't buy a beer (in many states), even if in uniform and home on leave from the war, until age 21.

In 1971, the Twenty Sixth Amendment took the wind out of the 21 to vote/18 to be drafted argument, mandating that voting rights would thereafter accrue at age 18.(18) In addition, many states lowered their drinking age to 18 during the 1960s and 1970s. As a result, the voting and drinking age issues were defused. However, as the years went by, the country began to experience a groundswell against the perils and consequences of underage drinking, particularly as to drinking and driving casualties. In 1984, Congress enacted the National Drinking Age Amendment of 1984 and, to "encourage" states to raise their respective drinking ages to 21, legislated that states not in compliance would in effect forfeit a percentage of their federal highway funds.(19) In South Dakota v. Dole (20), the argument was made that the Feds did not have the right to ram the $21 \mathrm{yr}$ old drinking age down the throats of the states. South Dakota felt that the drinking age for alcohol was a state province. The Feds said, and the Court agreed, that drinking (and therefore, driving) under age 21 affected interstate commerce, and losing "only" $5 \%$ of its Federal highway money was not coercion.(21) 


\section{B. You'd Better Slow Down}

In 1989, the Ninth Circuit Court of Appeals decided that losing 95\% of federal highway funds would not constitute coercion either.(22) The case involved the state of Nevada balking at the federally imposed 55mph national speed limit. I agree. I do not believe that threatening loss of $95 \%$ of federal highway funding is coercion; it is, in fact, in my opinion, extortion.

\section{A REVERSAL OF FORTUNE?}

In the 1990s, the Supreme Court seemed to take a breather from the expansionist approach to the Commerce Clause. In 1992, the Court decided that a federal law requiring a state to take title to waste generated within its borders if it failed to provide for permanent disposal of that waste, was an unconstitutional stretch.(23) A few years later, the Court decided that outlawing/criminalizing guns in/near schoolyards, although admirable in result, was not a federal matter.(24) And in Printz v. United States (25), part of the Brady Handgun Violence Protection Act mandating local police to do background checks prior to handgun purchases was struck down by the Court as improperly compelling state involvement in a federal program.

\section{ONCE A BULLY...}

Lest one get the impression that the Court has seen the light and Congress has gotten the message as far as laying off the Commerce Clause as a means to getting what it wants-whether entitled to it or not-one must remember that a leopard cannot change its spots, and as the saying goes, "Once a Bully, Always a Bully." The federal government wants a lowering of the Blood Alcohol Content (BAC) level for criminal drunken driving to .08\%. The battle cry has become: ".08 Or Else." Or Else what? Or else you will lose your federal highway funding. Sound familiar? The old coercion/extortion is back, and the holding hostage of federal highway funds, having proven a most effective tool for the federal government to "back door" its dreams, is alive and well and coming soon to a neighborhood near you.

\section{CONCLUSION}

Since 1942, commerce in the United States has grown exponentially. So has the use of the Commerce Clause by the federal government to enter areas that seemingly would never have been contemplated by the framers of the Constitution. The blame (or the praise, depending on your viewpoint) lays squarely on the shoulders of Congress and a Supreme Court which has placed its seal of approval on same. To be fair, both those branches of government have often been prodded by Chief Executives, who (well intentioned or not) saw the federal government as the answer to any and all of what ails the country. Though many in America pay lip service to capitalism, the expansion of the Commerce Clause has actually brought us closer to and promoted the "big brother" mentality of socialism.

\section{AUTHOR INFORMATION}

Patrick J. Reville, B.B.A., J.D., earned his B.B.A. degree in Accounting from Iona College, New Rochelle, New York, in 1965, and the Juris Doctor degree from the Fordham University School Of Law in 1968. He Joined the Iona College faculty in 1975, and is presently an Associate Professor of Business Law there. Attorney Reville has practiced law and accounting in Westchester County, New York, for forty (40) years, and presently devotes his practice time to Criminal Law, Small Businesses, Real Estate and Estates.

William A. Bottiglieri, Professor Bottiglieri is an Associate Professor of Accounting at Iona College, New Rochelle, New York. He joined the faculty in 1985 after having received his undergraduate and graduate degrees from Iona and his J.D. degree in 1983 from New York Law School, New York, New York. He has been a practicing CPA since 1979 and a practicing attorney since 1984. He has published and presented numerous articles in the income tax and legal fields and established the Taxpayer Assistance Program at Iona College under which accounting students provide income tax preparation services to community residents free of charge. 


\section{ENDNOTES}

1. U.S. CONST. art. I Sec. 8.

2. U.S. CONST. amend. X.

3. Gibbons v. Ogden, 22 U.S. 1 (1824).

4. Id.

5. U.S. CONST. amend. XVIII (repealed 1935).

6. U.S. CONST. amend. XXI.

7. Railroad Retirement Board v. Alton R. Co., 295 US 330 (1935).

8. A.L.A. Schechter Poultry Corp. v. United States, 295 U.S. 495, 548 (1935).

9. $\quad$ Carter v. Carter Coal Co., 298 U.S. 238 (1936).

10. Id. at 308.

11. NLRB v. Jones \& Laughlin Steel Corporation, 301 U.S. 37 (1937).

12. Id.

13. Wickard v. Filburn, 317 U.S. 111 (1942).

14. Katzenbach v. McClung, 379 U.S. 294 (1964).

15. Perez v. United States, 402 U.S. 146 (1971).

16. Kassell, et al, v. Consolidated Freightways Corporation of Delaware, 450 U.S. 662 (1981).

17. United States v. State Of Connecticut, 566 F. Supp. 571 (D. Conn. 1983).

18. U.S. CONST. amend. XXVI.

19. 23 USCS 158.

20. 483 U.S.203 (1987).

21. Id. at 211.

22. The State Of Nevada v. Samuel K. Skinner, 884 F.2d $445\left(9^{\text {th }}\right.$ Cir. 1989).

23. New York v. The United States, 505 U.S. 144 (1992).

24. United States v. Lopez, 514 U.S. 549 (1995).

25. 117 S.Ct. 2365 (1997). 
NOTES 